\title{
Профі.лактика розвитку стриктури відхідника при гемороїдектомії
}

\begin{abstract}
Мета роботи: вивчити ефективність та оцінити застосування розпрацьованої методики гемороїдектомії із застосуванням технічних прийомів профілактики розвитку стриктури відхідника у хворих на хронічний геморой III-IV ступеня.

Матеріали і методи. Проаналізовано результати хірургічного лікування 55 хворих на хронічний геморой III-IV ступеня. Результати досліджень та їх обговорення. У 2 (7,14 \%) із 28 хворих групи порівняння виникла компенсована післяопераційна стриктура відхідника, яка була підтверджена ізольованою рентгенографією і ліквідована консервативними заходами. У дослідній групі хворих через 2 місяці та 1 рік після проведеного операційного втручання за розпрацьованою методикою при проктологічному обстеженні та за результатами ізольованого рентгеноконтрастного дослідження відхідника даних за післяопераційну стриктуру не встановлено.
\end{abstract}

Ключові слова: гемороїдектомія; профілактика стриктури відхідника.

Постановка проблеми і аналіз останніх досліджень та публікацій. Стриктура відхідника (СВ) залишається одним із найбільш складних колопроктологічних захворювань. Частка СВ серед доброякісних захворювань прямої кишки не має тенденції до зниження і залишається в межах 0,91,7 \%, що змушує дослідників шукати нові підходи до лікування та профілактики даної патології $[1,2,6]$. У 90 \% хворих розвиток СВ пов'язують 3 перенесеними раніше операційними втручаннями з приводу геморою, хронічної кальозної анальної тріщини, гострокінцевих кондилом, параректальної нориці, гострого парапроктиту, випадання прямої кишки $[4,5]$. Після гемороїдектомії СВ діагностують у 1,5-3,8 \% хворих. За даними ряду авторів традиційні методи хірургічного лікування геморою ускладнюються розвитком СВ у 15 \% спостережень [1, 2].

Ізольоване рентгенологічне дослідження відхідника 3 використанням рентгеноконтрастних свічок дозволяє об'єктивно встановити наявність чи відсутність змін анального каналу та їх характер, що необхідно для вибору адекватної хірургічної тактики та оцінки безпосередніх і віддалених результатів хірургічного лікування [3].

Консервативне та операційне лікування післяопераційної СВ доволі складне та не завжди успішне. Тому під час проведення операційного втручання у хворих із хронічним гемороєм III-IV ступеня слід приділяти велику увагу заходам, які спрямовані на профілактику розвитку цього ускладнення.

Мета роботи: вивчити ефективність та оцінити застосування розпрацьованої методики гемороїдектомії із застосуванням технічних прийомів профілактики розвитку стриктури відхідника у хворих на хронічний геморой III-IV ступеня.
Матеріали і методи. Проаналізовані результати хірургічного лікування 55 хворих на хронічний геморой III-IV ступеня, які знаходилися на стаціонарному лікуванні в проктологічному відділенні Івано-Франківської обласної клінічної лікарні з 2017 по 2018 рр. До дослідної групи включені 27 (49,1 \%) хворих, яким операційне втручання при хронічному геморої III-IV ступеня проводили за розпрацьованою в клініці методикою, що передбачала застосування технічних прийомів профілактики розвитку САК. До групи порівняння включено 28 (50,9 \%) хворих, прооперованих за класичною методикою гемороїдектомії за Міліганом-Морганом.

Серед обстежених хворих - 34 (61,8 \%) чоловіків, 21 (38,2 \%) жінок віком від 28 до 76 років. Середній вік чоловіків - $(52,81 \pm 4,2)$ року, жінок $(44,35 \pm 2,9)$ року. Групи хворих зіставні за віком, статтю, ступенем тяжкості захворювання. Сроки спостереження у післяопераційному періоді від 2 місяців до одного року.

У хворих дослідної групи гемороїдектомію проводили за наступною методикою: після поетапної дивульсії і розтягнення відхідника, гемороїдектомію починали з внутрішнього гемороїдального вузла розміщеного на 11-й год, на ніжку внутрішнього гемороїдального вузла накладали затискач вище зубчатої лінії, після прошивання i перев’язування ніжки вузла ії̈ пересікали під гострим кутом до стінки прямої кишки, формували куксу відсіченого гемороїдального вузла, рештки слизової оболонки прямої кишки разом із залишками вузла висікали до перехідної складки. Пластику рани в напрямі від верхнього її кута до перехідної складки проводили окремими вузловими швами без захоплення слизової оболонки пря- 
мої кишки від дна рани з одного і з другого краю рани з захопленням кукси вузла так, щоб слизова оболонка прямої кишки при зав'язуванні вузла накривала лінію швів. Решту внутрішніх гемороїдальних вузлів видаляли аналогічно, після чого виконували гемороїдектомію зовнішніх гемороїдальних вузлів із пластикою шкірної рани “ззовні-всередину”.

Пересічення ніжки внутрішніх гемороїдальних вузлів під гострим кутом до стінки прямої кишки забезпечувало закриття дна рани без натягу. Зшивання рани без захоплення слизової оболонки прямої кишки в напрямі від верхнього кута до перехідної складки забезпечувало анатомічну адаптацію слизової оболонки без її некрозу та загоєння рани первинним натягом без формування гіпертрофічного рубця в просвіті відхідника. Зшивання шкірної рани в напрямі “ззовні-всередину” дозволяло анатомічно відновити цілісність тканин, запобігало її інфікуванню, деформації та звуженню дистального відділу відхідника.

Усім хворим дослідної групи та групи порівняння до операції перед випискою із стаціонару та через 2 місяці після проведеного хірургічного лікування проводили проктологічне обстеження (огляд параанальної ділянки, пальцеве дослідження прямої кишки, аноскопію та ректороманоскопію) та ізольоване рентгеноконтрастне дослідження відхідника із використанням спеціальних рентгенконтрастних свічок, що містять в своєму складі барію сульфат. Аналогічні дослідження проводили через 1 рік після операційного лікування.

\section{СПИСОК ЛІТЕРАТУРИ}

1. Помазкин В. И. Хирургическое лечение рубцових стриктур анального канала / В. И. Помазкин, Ю. В. Мансуров // Хирургия. Журнал им. Н. И. Пирогова. - 2011. - № 1. - С. 48-52.

2. Шевчук I. М. Стриктури анального каналу: причини, клінічні прояви / I. М. Шевчук, I. Я. Садовий // Український журнал хірургії. - 2012. - № 2 (17). - С. 82-85.

3. Шевчук И. М. Клиническая и лучевая диагностика послеоперационных стриктур анального канала / И. М. Шевчук, И. Я. Садовый, М. И. Яворский // Хирургия. Восточная Европа. - 2013. - № 1 (5). - С. 47-52.

\section{REFERENCES}

1. Pomazkin, V.I., \& Mansurov Y.V. (2011). Khirurgicheskoye lecheniye rubtsovyh striktur analnogo kanala [Surgical treatment of stricture of anal canal]. Khirurgiya. Zhurnal im. N.I. Pirogova - Surgery. Journal by N.I. Pirogov, 1, 48-52 [in Russian].

2. Shevchuk, I.M., \& Sadovyi, I.Y. (2012). Stryktury analnoho kanalu: prychyny, klinichni proiavy [Strictures of anal canal: causes, clinical manifestations]. Ukrainskyi zhurnal khirurhii -
Результати досліджень та їх обговорення. В ранньому післяопераційному періоді у 2 (7,14 \%) iз 28 хворих із групи порівняння спостерігали виникнення компенсованої післяопераційної СВ, що призвело до тривалого перебування хворих у стаціонарі. Наявність СВ була об'єктивно підтверджена ізольованою рентгенографією відхідника. Ліквідувати СВ у цих хворих вдалось консервативними заходами. При контрольних оглядах через 2 місяці і 1 рік клінічних та об'єктивних даних за СВ у пацієнтів не було.

У дослідній групі хворих через 2 місяці та 1 рік після проведеного операційного втручання за розпрацьованою методикою при проктологічному обстеженні та за результатами ізольованого рентгеноконтрастного дослідження відхідника даних за післяопераційну СВ не встановлено.

Висновки. У хворих на хронічний геморой III-IV ступеня застосування розпрацьованої методики гемороїдектомії із застосуванням технічних прийомів профілактики розвитку стриктури відхідника дозволило уникнути її виникнення у всіх прооперованих хворих, натомість у групі порівняння виникнення компенсованої післяопераційної стриктури відхідника спостерігали в 7,14 \% хворих.

Перспективи подальших досліджень. Частоту виникнення стриктури відхідника і результати iї хірургічного лікування буде вивчено у хворих на хронічну кальозну анальну тріщину.

4. Ettorre G. M. Anoplasty with House advancement flap for anal stenosis after hemorrhoidectomy. Report of a clinical case / G. M. Ettorre, L. Paganelli, L. Alessandroni // Chir. Ital. - 2001. - No. 53. - P. 571-574.

5. Garcea G. Management of benign rectal strictures / G. Garcea, C. D. Sutton, T. D. Lloyd // Dis. Colon. Rectum. - 2003. - No. 46. - P. 1451-1460.

6. Habr-Gama A. Surgical treatment of anal stenosis: assessment of 77 anoplasties / A. Habr-Gama, C. W. Sobrado, S. E. de Araujo // Clinics. - 2005. - No. 60. - P. 17-20.

Ukrainian Journal of Surgery, 2 (17), 82-85 [in Ukrainian]. 3. Shevchuk, I.M., Sadovyi, I.Y., \& Yavorskiy, M.I. (2013). Klinicheskaya i luchevaya diagnostika posleoperatsionnykh striktur analnogo kanala [Clinical and radiation diagnosis of postoperative strictures of anal canal]. Khirurgiya. Vostochnaya Yevropa - Surgery. Eastern Europe, 1 (5), 47-52 [in Russian].

4. Ettorre, G.M., Paganelli, L., \& Alessandroni, L. (2001). Ano- 
plasty with House advancement flap for anal stenosis after hemorrhoidectomy. Report of a clinical case. Chir. Ital. 53 571-574.

5. Garcea, G., Sutton, C.D., \& Lloyd, T.D. (2003). Management of benign rectal strictures. Dis. Colon. Rectum, 46, 1451-1460. 6. Habr-Gama, A., Sobrado, C.W., de Araujo, S.E. (2005) Surgical treatment of anal stenosis: assessment of 77 anoplasties. Clinics, 60, 17-20.

Отримано 03.03.2020

Електронна адреса для листування: kushch@i.ua

\author{
I. M. SHEVCHUK, O. V. NOVYTSKY, A. L. SHAPOVAL, I. YA. SADOVYI \\ Ivano-Frankivsk National Medical University
}

\title{
PREVENTION OF STRICTURE OF ANAL CANAL DURING HEMOROIDECTOMY
}

The aim of the work: to study the effectiveness and evaluate the application of the developed technique of hemorrhoidectomy with the use of preventing the stricture of anal canal in patients with chronic hemorrhoids of III-IV degree.

Materials and Methods. The results of surgical treatment of 55 patients with chronic hemorrhoid grade III-IV were analyzed.

Results and Discussion. 2 (7.14 \%) of 28 patients of comparison group had postoperative stricture of the anal canal, which was confirmed by isolated X-ray study and eliminated by conservative measures. In the patients of experimental group postoperative anal stricture was not found after 2 months and 1 year after the surgery by the invented method.

Key words: hemorrhoidectomy; prevention stricture of anal canal.

И. М. ШЕВЧУК, О. В. НОВИЦКИЙ, А. Л. ШАПОВАЛ, И. Я. САДОВЫЙ

Ивано-Франковский национальный медицинский университет

\section{ПРОФИ.ААКТИКА СТРИКТУР АНАЛЬНОГО КАНАЛА ПРИ ГЕМОРРОИДӘКТОМИИ}

Цель работы: изучить эффективность и оценить применение разработанной методики геморроидэктомии с применением технических приемов профилактики развития стриктуры анального канала у больных хроническим геморроем III-IV степени. Материалы и методы. Проведен анализ результатов лечения 55 больных хроническим геморроем III-IV степени.

Результаты исследований и их обсуждение. В 2 (7,14 \%) из 28 больных группы сравнения возникла компенсированная послеоперационная стриктура анального канала, подтверджденная изолированной рентгенографией анального канала и ликвидирована консервативными мероприятиями. В исследуемой группе больных через 2 месяца и 1 год после проведенного оперативного вмешательства, по разработанной методике, при проктологическом обследовании и по результатам изолированного рентгеноконтрастного исследования анального канала данных о послеоперационной стриктуре не выявлено.

Ключевые слова: геморроидэктомия; профилактика стриктуры анального канала. 